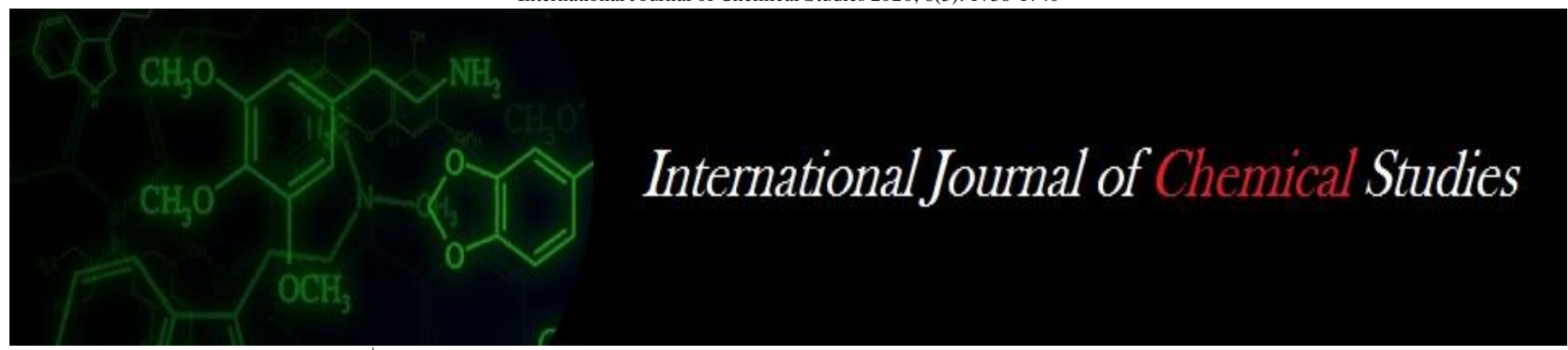

P-ISSN: 2349-8528

E-ISSN: 2321-4902

www.chemijournal.com

IJCS 2020; 8(3): 1738-1740

(C) 2020 IJCS

Received: 06-03-2020

Accepted: 08-04-2020

Seerat Rizvi

Division of Vegetable Science, Sher-eKashmir University of Agricultural Sciences and Technology of Kashmir, Shalimar, Srinagar, Jammu \& Kashmir, India

Faheema Mushtaq

Division of Vegetable Science, Sher-eKashmir University of Agricultural Sciences and Technology of Kashmir,

Shalimar, Srinagar, Jammu \&

Kashmir, India

K Hussain

Division of Vegetable Science, Sher-eKashmir University of Agricultural Sciences and Technology of Kashmir, Shalimar, Srinagar, Jammu \& Kashmir, India

Syeda Farwah

Division of Vegetable Science, Sher-e Kashmir University of Agricultural Sciences and Technology of Kashmir, Shalimar, Srinagar, Jammu \& Kashmir, India

\section{Baseerat Afroza}

Division of Vegetable Science, Sher-eKashmir University of Agricultural Sciences and Technology of Kashmir, Shalimar, Srinagar, Jammu \&

Kashmir, India

\section{Syed Mazahir Hussai}

Division of Vegetable Science, Sher-eKashmir University of Agricultural Sciences and Technology of Kashmir, Shalimar, Srinagar, Jammu \&

Kashmir, India

\section{Sana saleem}

Division of Vegetable Science, Sher-eKashmir University of Agricultural Sciences and Technology of Kashmir, Shalimar, Srinagar, Jammu \&

Kashmir, India
Corresponding Author: Seerat Rizvi

Division of Vegetable Science, Sher-eKashmir University of Agricultural Sciences and Technology of Kashmir, Shalimar, Srinagar, Jammu \&

Kashmir, India.

\section{Correlation analysis for various growth and yield attributing traits in potato (Solanum tuberosum L.) genotypes}

\author{
Seerat Rizvi, Faheema Mushtaq, K Hussain, Syeda Farwah, Baseerat \\ Afroza, Syed Mazahir Hussain and Sana saleem
}

DOI: https://doi.org/10.22271/chemi.2020.v8.i3x.9447

\begin{abstract}
In the present study twelve potato genotypes collected from various agro-climatic regions of India were evaluated in three diverse environments viz., SKUAST-K, Shalimar, Krishi Vigyan Kendra, Budgam and MRCFC Khudwani during Kharif 2018. The experiments were laid out in complete randomized block design with three replications at each location. From the present study it was observed that economically important trait i.e., total tuber yield hectare ${ }^{-1}$ (q) showed positive and significant association with plant height $(\mathrm{cm})$, plant spread $(\mathrm{cm})$, number of stems hill-1 of tubers plant ${ }^{-1}$, but positive and non-significant association with days to initiation of germination, indicating that improvement in yield could be brought about by selection of these component traits.
\end{abstract}

Keywords: Traits, potato, correlation analysis.

\section{Introduction}

Potato (Solanum tuberosum L.) $(2 \mathrm{n}=4 \mathrm{x}=48)$, belonging to family solanaceae, is native to Andean plateau of South America. It was introduced to India in early seventeenth century most probably by Portuguese sailors and spread by the Britishers to the hills of North India where it flourished in the colonial home gardens (Singh et al., 2016) ${ }^{[13]}$. It comprises about 200 species mostly confined to American continent. Potato can grow from sea level up to more than 4000 meter altitude. Most of the species of potato produce tubers but there are some which do not. Two tuber forming species namely Solanum tuberosum sub species tuberosum and to a lesser extent, Solanum tuberosum sub species andigena have been exploited worldwide for commercial cultivation. Among the wild Solanum species, there is a lot of variability in plant type, tuber shape, size, colour, cooking quality, taste, etc. and also in their adaptability to different climates. The large variability available among the species has not yet been fully exploited.

Potato is an annual and herbaceous plant that produces edible underground tubers that are used as vegetable. Potato has occupied important place among non-cereal food crops worldwide. It has been established as an important cool season crop in the hills as well as in plains. Potato is an important temperate vegetable that has adapted well for cultivation under subtropical conditions of India and the world. It is one of the most important food crop both in developed as well as developing countries. Potato has the capacity to produce maximum calories, vitamins, minerals and proteins per hectare per day than any other food crops. It is considered as a nourishing and wholesome food. Its low energy density is advantageous when eaten without much added fat. Hence, potato is readily accepted as a major part of a meal, and meal without potato is considered incomplete.

Correlation coefficient tells whether the mutual relationship between a pair of traits is positive or negative. Estimation of correlation coefficient among the yield contributing variables is necessary to understand the direction of selection and to maximize yield in shortest period of time. Genetic correlation indicates the relative importance of trait(s) on which greater emphasis should be made in selection for yield. Johnson et al. (1955) ${ }^{[3]}$ found that genotypic correlation coefficients provide a measure of association between various traits and help to identify the traits that may be useful in selection. 
The correlation coefficients, however, measure the nature and magnitude of association between different traits. Component analysis of this relationship reveals the importance of most important traits towards the yield.

\section{Materials and methods}

The present investigation was conducted during 2018 at three locations viz., Vegetable Experimental Farm, Sher-e-Kashmir University of Agricultural sciences and Technology. The experimental field is located at the main campus, Shalimar, Srinagar which is $15 \mathrm{~km}$ away from Srinagar city on the foot hills of Mahadev. The altitude of the location is 1685 meters above mean sea level and situated at $34^{\circ} .1^{\prime}$ North latitude and $74^{\circ} .89^{\prime}$ East longitude. Krishi Vigyan Kendra, Budgam. The research station is located at $34^{\circ} .07^{\prime}$ North latitude and $74^{\circ} .70^{\prime}$ East longitude in central Kashmir about $11 \mathrm{~km}$ away from Srinagar city. The location is situated at 1610 meters above sea level \&Vegetable experimental farm, Mountain Research Centre for Field Crops, Khudwani. The research station is located in the South of Kashmir about $56 \mathrm{~km}$ from Srinagar. The location is 1671 meters above mean sea level and situated at $34^{\circ} \mathrm{N}$ latitude and $74^{\circ} \mathrm{E}$ longitude. The experiment was laid in a completely randomized block design with three replications at each location. The experimental material consists of twelve genotypes maintained at a spacing of $60 \mathrm{~cm} \times 20 \mathrm{~cm}$. Observations were recorded on traits viz., days to initiation of germination, plant height $(\mathrm{cm})$, plant spread $(\mathrm{cm})$, stem diameter, number of stems hill ${ }^{-1}$, leaf area $(\mathrm{cm})^{2}$, number of tubers plant ${ }^{-1}$ and total tuber yield hectare ${ }^{-1}$ (q) Statistical analysis for calculation of correlation was worked out as per Panse and Sukhatme (1985) ${ }^{[9]}$.

\section{Result and Discussion}

A quick glance at Table 1 revealed that, in general, the estimates of genotypic correlation coefficients of growth and yield attributing characters indicated a strong inherent association between various traits under study and the masking effect of environment in the total expression of genotypes or a strong inherent association between various traits under study. Similar findings have also been reported by Ramanjit et al. (2001), Roy and Singh (2006) and Ummyiah et al. (2013) ${ }^{[10,12,15]}$. In the present study, the most important trait total tuber yield hectare ${ }^{-1}(\mathrm{q})$ exhibited significant positive correlation with number of stems hill ${ }^{-1}$, leaf area $\left(\mathrm{cm}^{2}\right)$, plant height $(\mathrm{cm})$, plant spread $(\mathrm{cm})$ and number of tubers plant ${ }^{-1}$ at genotypic levels thereby suggesting that these characters could be considered useful for increasing tuber yield in potato and any improvement in these characters would bring enhancement in the most complex characters i.e, tuber yield.
Days to initiation of germination was positively and significantly associated with plant height $(\mathrm{cm})$, plant spread $(\mathrm{cm})$, number of stems hill ${ }^{-1}$, leaf area $(\mathrm{cm})^{2}$ and number of tubers plant ${ }^{-1}$. Similarly, Plant height exhibited positive and significant correlation with plant spread $(\mathrm{cm})$, stem diameter $(\mathrm{cm})$, number of stems hill ${ }^{-1}$, leaf area $(\mathrm{cm})^{2}$ and total tuber yield hectare ${ }^{-1}$ (q). Plant spread showed positive and significant association with stem diameter $(\mathrm{cm})$, number of stems hill ${ }^{-1}$, leaf area $(\mathrm{cm})^{2}$, number of tubers plant ${ }^{-1}$ and total tuber yield hectare ${ }^{-1}(\mathrm{q})$. Stem diameter showed significant and positive association with number of stems hill ${ }^{-1}$, leaf area $(\mathrm{cm})^{2}$ and total tuber yield hectare ${ }^{-1}$ (q). Number of stems hill ${ }^{1}$ showed positive and significant association with leaf area $(\mathrm{cm})^{2}$, number of tubers plant ${ }^{-1}$ and total tuber yield hectare ${ }^{-1}$ (q). Leaf area showed positive and significant relation with number of tubers plant ${ }^{-1}$ and total tuber yield hectare ${ }^{-1}$ (q), thereby indicating that the change in one character will lead to simultaneous change in the other. The significant and positive association among the characters suggests the scope for improvement of these traits, which may influence each other and in turn may improve the tuber yield. Significant positive correlation coefficients have also been reported by Bhagowati et al. (2002) [1] for plant height and leaf numbers, tuber numbers and average tuber weight, primary branch numbers and leaf numbers, tuber numbers and between leaf numbers and average tuber weight; Ozkaynak et al. (2003) ${ }^{[7]}$ for yield with plant height, number of tubers plant ${ }^{-1}$ and average tuber weight; Luthra et al. (2005) ${ }^{[5]}$ for yield with plant height, number of tubers ${ }^{-1}$, stems hill ${ }^{-1}$, tuber yield plant ${ }^{-1}$ and tuber weight; Dereje and Basavaraja (2005) ${ }^{[2]}$ for tuber yield with plant spread; Pandey et al. (2005) ${ }^{[8]}$ for yield and dry matter content; Rasool et al. (2007) ${ }^{[11]}$ for yield with number of tubers plant ${ }^{-1}$, average weight tuber ${ }^{-1}$ (tuber size), plant height, diameter of main stem and number of main and secondary stems plant ${ }^{-1}$; Khayatnezhad et al. (2011) ${ }^{[4]}$ for tuber yield with number of main stem plant ${ }^{-1}$, plant tuber weight and plant height; Nasiruddin et al. (2014) ${ }^{[6]}$ for tuber yield plant ${ }^{-1}$ with plant height, main stem number plant ${ }^{-1}$, canopy size, leaf area plant ${ }^{-1}$ and dry matter; Singh et al. (2015) ${ }^{[14]}$ for tuber yield hectare ${ }^{-1}$ with marketable tuber yield ha $^{-1}$, fresh weight of tubers plant ${ }^{-1}$, number of shoots plant ${ }^{-1}$, number of tuber plant ${ }^{-1}$ and plant emergence percent.

The traits exhibiting the strong positive genotypic correlation coefficients with tuber yield and among themselves may be taken into consideration during the selection process for effective improvement in the breeding programme and emphasis should be given on traits like number of tubers plant $^{-1}$ and average tuber weight for the development of high yielding genotypes in potato.

Table-1: Estimates of genotypic (above diagonal) correlation coefficients among various growth and yield attributing traits in Potato (Solanum tuberosum $\mathrm{L}$.)

\begin{tabular}{|c|c|c|c|c|c|c|c|c|c|}
\hline \begin{tabular}{|l} 
S. \\
No.
\end{tabular} & Parameters & \begin{tabular}{|c|} 
Days to \\
initiation of \\
germination
\end{tabular} & $\begin{array}{c}\text { Plant } \\
\text { height } \\
(\mathbf{c m})\end{array}$ & $\begin{array}{c}\text { Plant } \\
\text { spread } \\
(\mathbf{c m})\end{array}$ & $\begin{array}{c}\text { Stem } \\
\text { diameter } \\
(\mathrm{cm})\end{array}$ & $\begin{array}{l}\text { Number of } \\
\text { stems hill }^{-1}\end{array}$ & $\begin{array}{c}\text { Leaf area } \\
\left(\mathrm{cm}^{2}\right)\end{array}$ & $\begin{array}{c}\text { Number } \\
\text { of tubers } \\
\text { plant }^{-1}\end{array}$ & $\begin{array}{c}\text { Total tuber } \\
\text { yield hectare }^{-1} \\
\text { (q) }\end{array}$ \\
\hline 1. & Days to initiation of germination & 1.00 & $0.325^{*}$ & $0.235 *$ & 0.108 & $0.791 *$ & $0.339 *$ & $0.657 *$ & 0.186 \\
\hline 2. & Plant height $(\mathrm{cm})$ & & 1.00 & $0.445 *$ & $0.666^{*}$ & $0.241 *$ & $0.823 *$ & 0.165 & $0.411^{*}$ \\
\hline 3. & Plant spread $(\mathrm{cm})$ & & & 1.00 & $0.586^{*}$ & $0.819 *$ & $0.853^{*}$ & $0.213^{*}$ & $0.312 *$ \\
\hline 4. & Stem diameter $(\mathrm{cm})$ & & & & 1.00 & $0.592 *$ & $0.230 *$ & 0.135 & $0.314 *$ \\
\hline 5. & Number of stems hill- ${ }^{-1}$ & & & & & 1.00 & $0.807 *$ & $0.621 *$ & $0.297 *$ \\
\hline 6. & Leaf area $\left(\mathrm{cm}^{2}\right)$ & & & & & & 1.00 & $0.231 *$ & $0.326^{*}$ \\
\hline 7. & Number of tubers plant ${ }^{-1}$ & & & & & & & 1.00 & $0.345^{*}$ \\
\hline 8. & Total tuber yield hectar & & & & & & & & 1.00 \\
\hline
\end{tabular}




\section{References}

1. Bhagowati RR, Saikia M, Sut D. Variability, heritability, genetic advance and character association in True Potato Seed (TPS) populations. Journal Agricultural Science Society North East India. 2002; 15(1):119-122.

2. Dereje R, Basavaraja N. Correlation and path analysis in potato. (Solanum tuberosum L.). Journal of Indian Potato Association. 2005; 32(3-4):213-256.

3. Johnson HW, Robinson HF, Comstock RE. Estimation of genetic and environmental variability in soybean. Agronomy Journal. 1955; 47:477-483.

4. Khayatnezhad M, Shahriari R, Gholamin R, Jamaati-eSomarin S. Zabihi-e- Mahmoodabad, R et al. Correlation and Path Analysis between Yield and Yield Components in Potato (Solanum tubersumL.). Middle-East Journal of Scientific Research. 2011; 7(1):17-21.

5. Luthra SK, Gopal J, d PC. Genetic divergence and its relationship with heterosis in potato. Potato Journal. 2005; 32(1-2):37-42.

6. Nasiruddin M., Haydar FMA, Islam AKMR, Hossain MM. Study of Genetic Variability and Correlation of Potato (Solanum tuberosum L.) genotypes grown in Bangladesh. Plant Environment Development. 2014; 3(2):09-13.

7. Ozkaynak E, Samanci B, Cetin MD. Correlation and path coefficient analysis of yield components in potato (Solanum tuberosum L.). Turkish Journal of Field Crops. 2003; 8(2):51-56.

8. Pandey KK, Singh SV, Manivel P. Genetic variability and causal relationship over seasons in potato. Crop Research. 2005; 29(2):277-281.

9. Panse VG, Sukhatme PV. Statistical methods for agricultural workers. Indian Council of Agricultural Research, New Delhi, 1985; 152-156.

10. Ramanjit K, Singh N, Kler DS. Correlation studies among leaf area index, tuber number, tuber weight, dry matter production and tuber yield in autumn sown potato. Environment and Ecology. 2001; 19(1):19-22.

11. Rasool AZ, Mojtaba F, Davood HP. Sequential Path Analysis of Yield Components in Potato. Potato Research. 2007; 49:273-279.

12. Roy AK, Singh PK. Genetic variability, heritability and genetic advance for yield in potato (Solanum tuberosum L.). International Journal of Plant Sciences. 2006; 1(2):282-285.

13. Singh H, Madhu S, Aakash G, Monika B. Effect of nitrogen and sulphur on growth and yield attributes of potato (Solanum tuberosum L.). International Journal of Plant and Soil Science. 2016; 9:1-8.

14. Singh P, Sharma PK, Banjara NC, Sahu NP. Sharma R. Variability, heritability, genetic advance, correlation and path analysis between yield and yield components in potato (Solanum tuberosum L.). Ecology, Environment and Conservation Paper. 2015; 21(2):1093-1097.

15. Ummyiah HM, Khan SH, Jabeen N, Junaif, N Hussain K. Intertrait relationship and path analysis in potato. Progressive Horticulture. 2013; 45(1):201-205. 